\title{
THE EFFECT OF LEARNING STYLES AND MOTIVATION ON INDONESIAN STUDENTS' ENGLISH ACHIEVEMENT
}

\author{
Hery Yufrizal \\ Department of English Education, Universitas of Lampung, \\ E-mail: heryyufrizal@gmail.com \\ Sudirman \\ Department of English Education, University of Lampung \\ E-mail: sudirman@yahoo.comm \\ Basturi Hasan \\ Department of English Education, University of Lampung \\ E-mail: basturi_hasan@yahoo.com
}

APA Citation: Yufrizal, H., Sudirman, \& Hasan, B. (2015). The effect of learning styles and motivation on Indonesian students' English achievement. Indonesian EFL Journal, 1(2), 232-241

\begin{abstract}
This research aims to find out whether there is any significant interaction between motivation and learning style on students' English achievement in Bandar Lampung. This research is a non-experimental study with variant analysis study. The research involves 430 students of Science Department, Faculty of Teaching and Education, University of Lampung, Indonesia. Data were taken by giving a set of test in which validity and reliability are tested. Data for motivation and learning styles were taken from students' reponses to multiple choice questionnaire each consisting of 40 questions. The results of the analysis show that there is no significant interaction between motivation and learning styles on students' English Achievement. This means that the combination of motivation and learning styles cannot distinguish between high achiever students and the lower ones. Learning styles have significant influence on students' English achievement. Students with different learning styles have different English achievement. Motivation does not have significant effect on students' English achievement. Students with different motivation did not have different result of English achievement.
\end{abstract}

Keywords: motivation, learning styles, English achievement.

\section{INTRODUCTION}

In second and foreign language

learning, there are three aspects that must mastered by the learners. The aspects are pronunciation, grammar and structure, and vocabulary. These aspects are blended in three four language skills: (listening skill, speaking skill), reading skill and writing skill. One can be called proficient when he/she can master these three aspects and skills. However, as Bambang Setiyadi confessed in his professorship inauguration on November 2009 that the teaching of English in Indonesia has failed. This failure is proven by the facts that high school and even university graduates in Indonesia use English for communication and other purposes.
Learning achievement can be used as an indicator for students' language capability. Djaali, 2008 states that the higher the learning ability, the higher the learning achievement will be. However, learning English as foreign or second language is not similar to the learning of other subjects. In learning general subjects, students' success is measured by the mastery of the subject. Learning language is much more complex, learning success is not only measured by the learning achievement but also by mastering the language as well as using the language as a complete skill.

Many factors influence the success of failure of second and foreign language learning. Some of the factors are coming from 
the external side of the learning called external factors, and some coming from the internal (internal factors (see Brown, 2009). Among the external factors are: school environment, teachers, learning facilities, etc. Among the internal factors are: students' age, motivation, attitude, learning style, learning strategies, and other affective factors. Two factors among those factors are leaning styles and motivation. Many studies have discussed the roles of learning styles and motivation on students' achievement in foreign language learning and general subject. This research studies use different theoretical and research paradigms.

In terms of the relationship between learning styles and general subjects, some studies have tried to find out this relationship. Among others are Arianti (2013), Utami (2013), and Bakri (2012), all seem to agree that there is a significant correlation between students' learning styles and their achievement on their learning achievement of some content learning. In his research study, Yufrizal (2010) stated that students of junior and senior high schools in Tulang Bawang regency have different achievement in English based on their learning styles. Likewise Panduwinata (2012) in an experiment of writing ability of students in Lampung Polytechnic found that students with concrete learning style produce better writing results than students with analytic learning styles.

Sadewo (2011), Arianti (2013), Utami (2013), and Bakri (2012). These studies have shown that there is a significant correlation between students' learning motivation and their learning achievement. The higher the level of motivation the students have, the better students would achieve in their learning effort. However, there are some difference in research and construct paradigms among those studies resulting in different results of studies. A more compact research on this matter will give us clearer idea on how learning style and motivation affect learning particularly the learning of English as a second/foreign language in Indonesia.

This present study attempts to find out whether there is any significant effect of learning style and students' motivation on their achievement in learning English for the first year students of the University of Lampung. Students' learning styles preferences have been a major concern of some research. Reid (1987), for example, based on survey data, distinguished four perceptual learning modalities:

1. visual learning (for example, reading and studying charts);

2. auditory learning (for example, listening to lectures or audio tapes);

3. kinesthetic learning (involving physical responses); and

4. Tactile learning (hands-on learning, as in building models).

He then administered a questionnaire to 1,388 students of varying language backgrounds to investigate their preferred modalities. This revealed that the learners' preferences often differed significantly from those of native speakers of American English. They showed a general preference for kinesthetic and tactile learning styles, and for individual as opposed to group learning. Willing (1987) investigated the learning styles of 517 adult ESL learners in Australia. Based on their responses to a 30 -item questionnaire, Willing tried to identify how differences in cognitive learning styles affected learners' preferences in six different areas:

1. preferences for particular kinds of classroom activities;

2. preferences for particular types of teacher behavior;

3. preferences for particular grouping arrangements;

4. preferences for particular aspects of language which need emphasis;

5. preferences for particular sensory modes, such as visual, auditory, or tactile learning; and

6. Preferences for particular modes of learning on one's own outside class.

It was found that differences in cognitive styles affected learners' preferences for particular approaches to learning. For example, concrete learners tended to choose the following:

- In class, I like to learn by games. 
- I like to learn English by working in pairs.

Learners with analytical learning styles, however, reported the following preferences:

- I like to study grammar.

- I like the teacher to let me find my mistakes. [-2-]

Although Richards and Lockhart (1994) argue that such information can prove to be significant as to whether both teachers and learners approach learning in the same way, they still oppose the idea of putting "learners into boxes labeled according to cognitive styles" (pp. 62-63). Nunan (1989) points out that accommodating learners' needs and preferences is vital in designing a learnercentered curriculum. Such importance given to students' feelings has also been stressed in Barkhuizen's (1998) study, in which he reports an investigation of high school ESL learners' perceptions of the language teaching-learning activities presented in their classes. The outcome of such investigation surprised the teachers in those perceptions of teachers and students differed greatly from each other.

A series of research by Yufrizal (2000, 2001, 2009) also have shown that learning styles influence signifcantly on students' English achievement in Indonesia. He found that setudents with communicative learning styles tend to have higher achievement than students with other learning styles.

\section{METHOD}

A non-experimental quantitative with variant analysis (Gal et al. 1998) is used to achieve the objective of the study. The method used in the study is cross-sectional with a design of non-correlational ex-post de facto. (Setiyadi, 144). In this case, the research examines phenomena exist during the research without giving any treatment to the subjects, in which samples were given tests and questionnaire to get the data for students' achievement, learning styles, and motivation.

Population of the research is all grade 9 students at junior high schools in Bandar Lampung city. The sample was taken through purposive random sampling, i.e. by taking students from four kinds of schools: high rated public schools, high rated-private schools, lower rated public schools and lower rated private schools. Data for students' English achievement were gained by giving a set of English proficiency test (focusing on reading ability). Data for students' learning styles were taken by giving a set of questionnaire developed by Willing (1988) and was modified and translated into bahasa Indonesia by Yufrizal (2000). The questionnaire comprises 40 items with alternative answers. For motivation data, a set of standardized questionnaire was given to the students.

All data were then statistically analyzed using Multivariate Analysis of Variance (MANOVA) to see the interaction among the variables. In order to see the effect of learning and motivation toward students' English achievement, one way Analysis of Variance (ANOVA) was used.

\section{RESULTS AND DISCUSSION}

The following table illustrates the distribution and frequency of students' English achievement.

Table 1: Students' English achievement

\begin{tabular}{llll}
\hline No. & Interval & Frequency & Percentage \\
\hline 1. & $<30$ & 62 & 14,41 \\
\hline 2. & $31-40$ & 96 & 22,3 \\
\hline 3. & $41-50$ & 63 & 14,6 \\
\hline 4. & $51-60$ & 61 & 14,18 \\
\hline 5. & $61-70$ & 80 & 18,6 \\
\hline 6 & $71-80$ & 54 & 12,6 \\
\hline 7 & $>80$ & 24 & 5,56 \\
\hline & Total & 430 & $100 \%$ \\
\hline
\end{tabular}

The table shows that there was an evenly distributed students' achievement in English.
None of students are more superior to the others. 


\section{Learning styles}

As previously mentioned, in order to identify students' learning styles, a set of questionnaire consisting of 40 questions with multiple choice alternatives were given. The alternatives are: 1 strongly disagree, 2 disagree, 3 Agree, and 4 strongly agree. All students' answers were analyzed through data reduction factor analysis resulting four types of learning styles: a) Communicative, b) Concrete, c) Authority oriented, and analytic learning styles. Another style was added, that is 5) undecided or mixed styles referring to students with combination of style or nondominating style identified.

The number and percentage of students' learning styles and their English achievement is shown in the following table.

Table 2. Students' English achievement based on their learning styles.

\begin{tabular}{llcc}
\hline No. & Learning Styles & Frequency & \multicolumn{2}{c}{ Percentage } \\
\hline 1. & Communicative & 190 & 44.2 \\
\hline 2 & Concrete & 85 & 19.8 \\
\hline 3. & Authority oriented & 49 & 11.4 \\
\hline 4. & Gaya Analytic & 98 & 22.8 \\
\hline 5. & Undecided & 8 & 01.8 \\
\hline & Total & 430 & $100 \%$ \\
\hline
\end{tabular}

Table 2 shows that the highest percentage is students with communicative learning style 190 students (44.2\%). The second highest percentage is students with concrete learning styles with 98 students (19.8\%), this is followed by students with authority-oriented (85 students/29\%) and analytic learners (22.8\%). The least percentage is students with undecided learning style (01.8\%).

\section{Learning motivation}

To measure the students' motivation, a set of validated questionnaire consisting of 40 questions with four alternative: $\mathrm{a}=1, \mathrm{~b}=$ $2, c=3$ and $d=4$. Students' motivation was accumulated resulting three categories of motivation: high, middle, and low motivation. The distribution of students' motivation based on their English achievement is illustrated in the following table.

Table 3. Distribution and frequency of students' motivation

\begin{tabular}{llcc}
\hline No. & Learning motivation & Frequency & Percentage \\
\hline 1. & $<100$ low & 67 & 15.6 \\
\hline 2 & $101-110$ middle & 223 & 51.9 \\
\hline 3. & $>111$ high & 140 & 31.5 \\
\hline & Total & 430 & $100 \%$ \\
\hline
\end{tabular}

Table 3 shows that 223 people (51.9\%) have middle range motivation, 140 (31.5\%) students have high motivation, and 140 (15.6\%) students have low motivation.
The influence of learning styles on students English achievement

The following table shows the descriptive statistic of students' average score in English based on their learning styles.

Table 4. Descriptive of learning styles and students English achievement

\begin{tabular}{lrrrrrr}
\hline Score & N & Mean & Std. Deviation & Std. Error & Minimum & Maximum \\
\hline Comm & 190 & 55.9368 & 18.03425 & 1.30834 & 22.00 & 87.00 \\
\hline Conc & 85 & 54.5647 & 16.39356 & 1.77813 & 25.00 & 85.00 \\
\hline Auth & 49 & 45.0816 & 14.85883 & 2.12269 & 20.00 & 80.00 \\
\hline Anal & 98 & 47.5204 & 17.58527 & 1.77638 & 20.00 & 90.00 \\
\hline Undecided & 8 & 56.1250 & 18.13786 & 6.41270 & 30.00 & 75.00 \\
\hline Total & 430 & 52.5140 & 17.72487 & .85477 & 20.00 & 90.00 \\
\hline
\end{tabular}


The table shows that 190 students have communicative learning style gained the average score of 55.93 (SD. 18.03). Eighty five (85) students with concrete learning style had the average score of $54.56(\mathrm{SD}=18.05$. The number of students who have authority oriented is 49 with the average score of 45.08 $(S D=15.94)$. For students with analytic learning style, the average score was 47.52
( $S D=17.58)$. Finally, 8 students who have undecided-learning style had an average score of 52.51 (SD = 18.13).

In order to find out the difference of English average score of students with different styles, an ANOVA test was executed. The result of the statistical analysis is shown in the following table.

Table 5: The result of ANOVA test based students' learning styles

\begin{tabular}{lrrrrr}
\hline \multicolumn{5}{c}{ ANOVA } & \\
\hline Score & Sum of Squares & df & Mean Square & F & Sig. \\
\hline Between Groups & 7838.272 & 4 & 1959.568 & 6.561 & .000 \\
\hline Within Groups & 126941.144 & 425 & 298.685 & & \\
\hline Total & 134779.416 & 429 & & & \\
\hline
\end{tabular}

The table shows that the $\mathrm{F}$ count of the statistical analysis is 6,561 which is higher than the $\mathrm{F}$ table. This means that there is a significant effect of the learning styles on students' average score of English achievement. Students with different learning styles gained different average score of English achievement at 0.001 significant levels.
The effect of motivation on students English Achievement

Students were found three levels of motivation: low, middle, and high. The descriptive statistic of students' English score based on their level of motivation is presented in table 6 .

Table 6 the average score of English based on students' level of motivation

\begin{tabular}{|c|c|c|c|c|c|c|}
\hline \multicolumn{7}{|c|}{ Descriptive } \\
\hline Score & $\mathrm{N}$ & Mean & Std. Deviation & Std. Error & Minimum & Maximum \\
\hline 1 & 68 & 49.6471 & 18.21658 & 2.20908 & 20.00 & 87.00 \\
\hline 2 & 221 & 53.0452 & 17.62379 & 1.18550 & 20.00 & 87.00 \\
\hline 3 & 141 & 53.0638 & 17.63730 & 1.48533 & 22.00 & 90.00 \\
\hline Total & 430 & 52.5140 & 17.72487 & .85477 & 20.00 & 90.00 \\
\hline
\end{tabular}

Note: 1 = students with low motivation

2 = students with middle motivation

$3=$ students with high motivation

Table 6 shows that students with low motivation have an English achievement average score of 46.64 (SD $=18.21$ ). The number of students with middle motivation is 221 with an English achievement average score of $53.05(\mathrm{SD}=17.62)$ and students with high motivation 141 with an English achievement average score of 52.51 (SD = 17.72).

The result of ANOVA test on motivation and students' average score of English is shown in table 7 . 
Table 7. The result of ANOVA test on motivation and English achievement

\begin{tabular}{lcrrrr}
\hline \multicolumn{7}{c}{ ANOVA } & & & \\
\hline Score & Sum of Squares & df & Mean Square & F & Sig. \\
\hline Between Groups & 663.914 & 2 & 331.957 & 1.057 & .348 \\
\hline Within Groups & 134115.502 & 427 & 314.088 & & \\
\hline Total & 134779.416 & 429 & & & \\
\hline
\end{tabular}

The ANOVA test on students' motivation and their average score of English shows that the F count is 1,057 which is smaller than the $\mathrm{F}$ table for the number of sample. This means that there is no significant effect of motivation on students' English achievement. Students with different levels of motivation do not differ significantly in their Achievement of English.
Interaction between learning styles and motivation

In order to find out whether is a statistically significant interaction between learning styles and motivation on students' achievement of English, a multivariate analysis of variant (MANOVA) test was conducted. The result of the statistical analysis is iilustrated in table 8

Tabel 8. MANOVA test of motivation and learning styles on students'achievement

\begin{tabular}{lrrrrr}
\hline Source & $\begin{array}{c}\text { Type III Sum of } \\
\text { Squares }\end{array}$ & df & Mean Square & F & Sig. \\
\hline Corrected Model & $11766.139 \mathrm{a}$ & 14 & 840.438 & 2.835 & .000 \\
\hline Intercept & 277592.194 & 1 & 277592.194 & 936.490 & .000 \\
\hline Gaya & 9241.142 & 4 & 2310.285 & 7.794 & .000 \\
\hline Mot & 540.669 & 2 & 270.334 & .912 & .403 \\
\hline Style * mot & 3479.690 & 8 & 434.961 & 1.467 & .167 \\
\hline Error & 123013.277 & 415 & 296.418 & & \\
\hline Total & 1320597.000 & 430 & & & \\
\hline Corrected Total & 134779.416 & 429 & & & \\
\hline a. R Squared $=.087$ (Adjusted R Squared $=.057)$ & & & & \\
\hline
\end{tabular}

Tabel 8 shows the results of MANOVA test as follow:
a) Learning style have a significant effect on students' Anglish achievement ( $\mathrm{F}=7.794)$ at the significant level of 0.005 .
b) Motivation does not havea significant effect on students' English achievement $(\mathrm{F}=0.912)$
c) There is no significant interaction between learning styles and motivation on students' English achievement.

Statistical analysis showed that there is a significant effect of learning styles and students' English achievement at junior high schools in Bandar Lampung city. There are significan differences of students' average score in English of students with different learning style $(\mathrm{F}=.561)$ at the significant level of 0.001. Differences of students' English achievement according their learning styles are illustrated in the following figure. 
Figure 1. Students' average score of English based on their learning styles

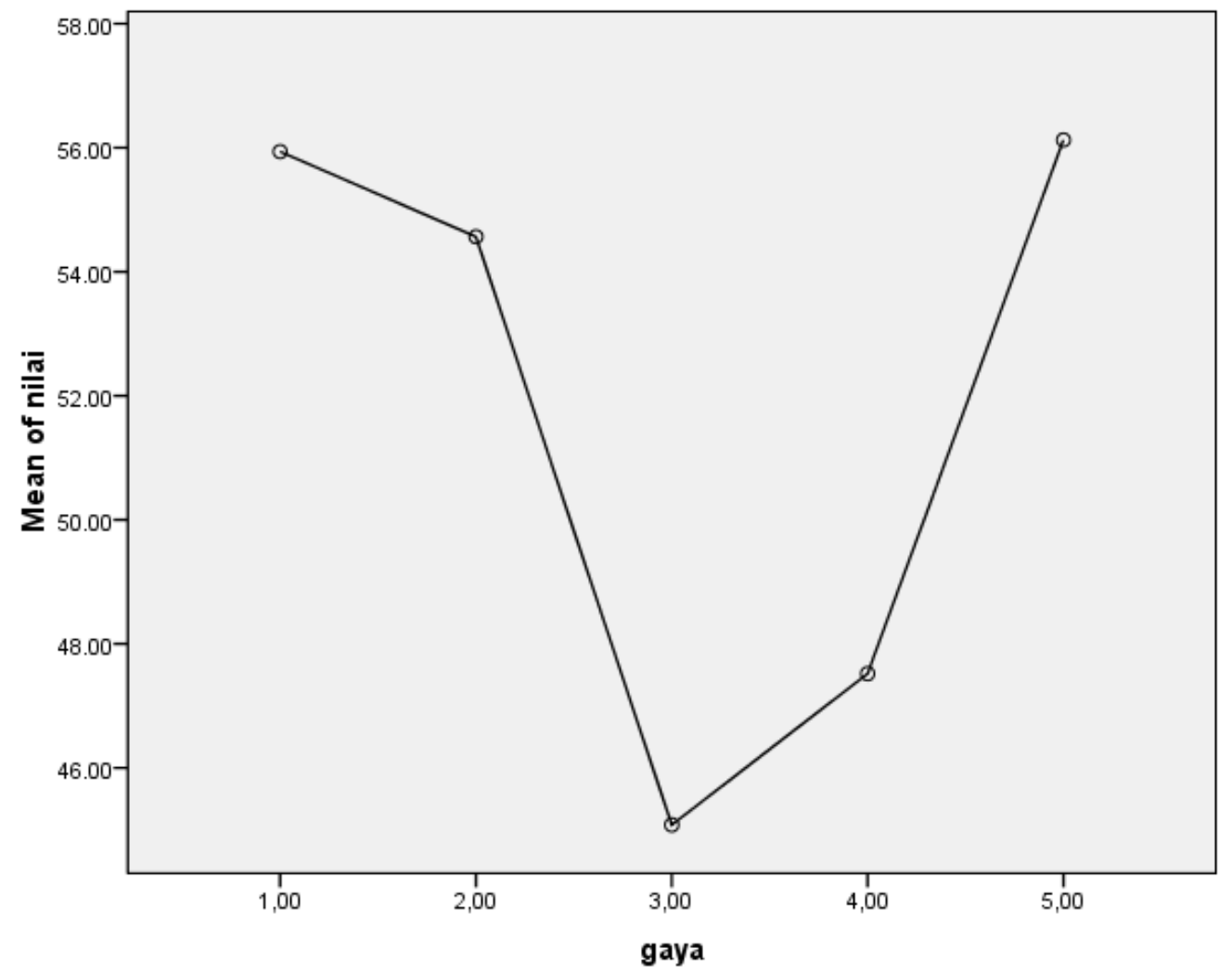

Note: Learning styles $1=$ communicative, $2=$ concrete, $3=$ authority-oriented, $4=$ analytic, 5 = Undecided

Figure 1 shows that students with communicative learnig style and undecided have the highest scores in English compared to students with other learning styles. Students with concrete learning styles had the third highest average score, higher than students with analytic and authority oriented learners. The lowest average scores were gained by the students with authority oriented styles. This result of analysis confirms previous studies on the role of learning styles on students' English achievement using the same model of learning style measurement (Yufrizal, 2010; None Tis'ah, 2011; Panduwinata, 2012). In his research study, Yufrizal (2010) stated that students of junior and senior high schools in
Tulang Bawang regency have different achievement in English based on their learning styles. Likewise Panduwinata (2012) in an experiment of writing ability of students in Lampung Polytechnic found that students with concrete learning style produce better writing results than students with analytic learning styles.

On the aspect of motivation, the statistical analysis of the current research has shown that motivation does not have a significant effect on students' English achievement at junior high schools in Bandar Lampung city. Students with different level of motivation do not differ in their English achievement. This can be illustrated from the following figure. 
Figure 2. Means of students' motivation on their English achievement

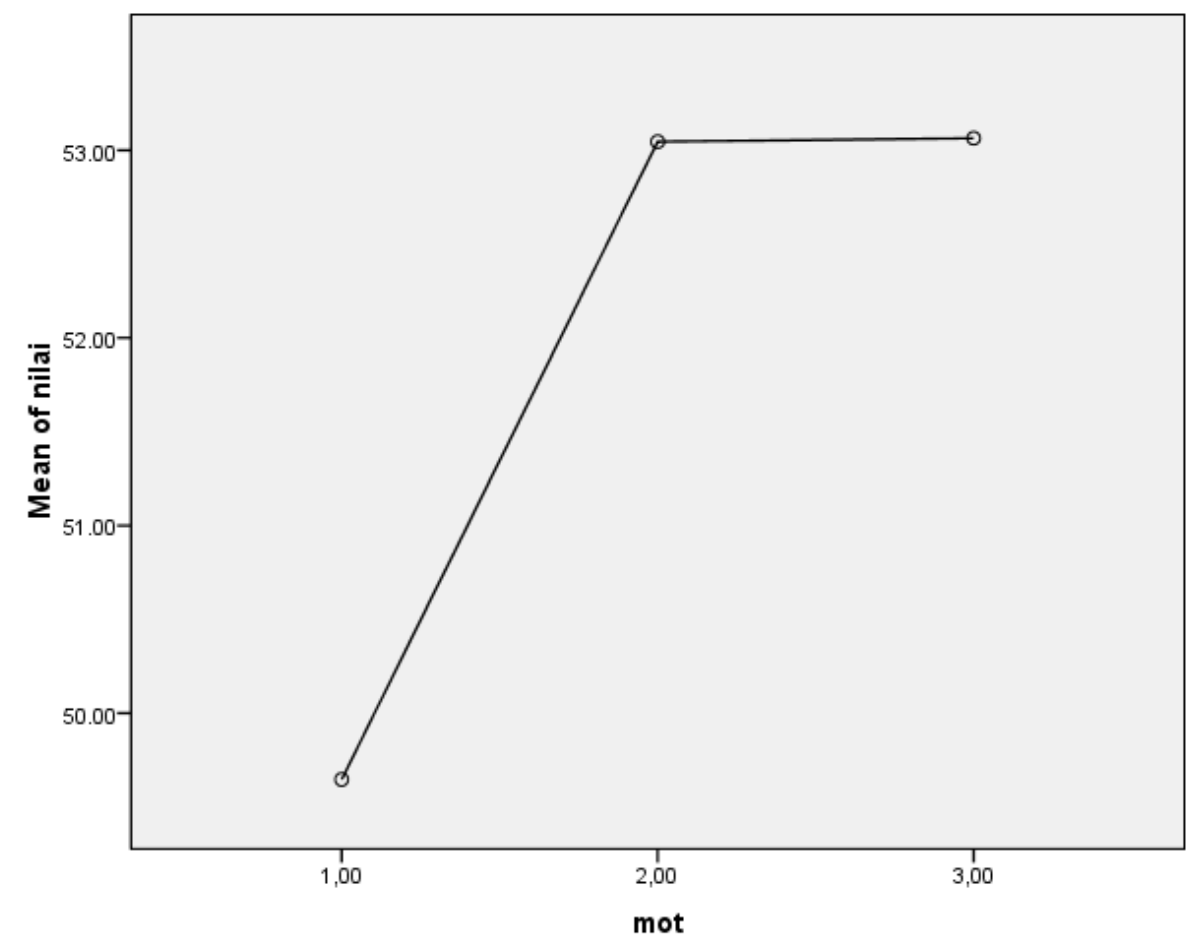

Note: Students' motivation $1=$ low, $2=$ middle, $3=$ high

Figure 2 shows that students with high motivation have the average score relatively similar to students with middle level of motivation. The highest and the middle level motivation students have relatively higher average score of English achievement. This result seems to contradict other previous studies on the effect of motivation on students' learning achievement. The higher the level of motivation the students have, the better students would achieve in their learning effort. In this case, we assume that differences in the result of analysis of the current research and other previous studies of motivation are due to the statistical analysis model. The current study looks at the motivation by comparing the students' achievement according to their level of motivation using ANOVA test paradigm, while other previous studies use correlational and regression test analysis.

In terms of statistical relationship between the students learning styles and their level of motivation on English achievement, the current research has shown that the $\mathrm{F}$ value for the statistical interaction is 1,467 lower than the $F$ table of the number of sample. This value means that there is no significant interaction between students' learning styles and their level of motivation. Relative interaction between learning styles and motivation on students' English achievement can be illustrated by the following figure. 
Hery Yufrizal, Sudirman, Basturi Hasan

The Effect Of Learning Styles And Motivation On Indonesian Students' English Achievement

Figure 3. Interaction between learning styles and motivation

\section{Estimated Marginal Means of nilai}

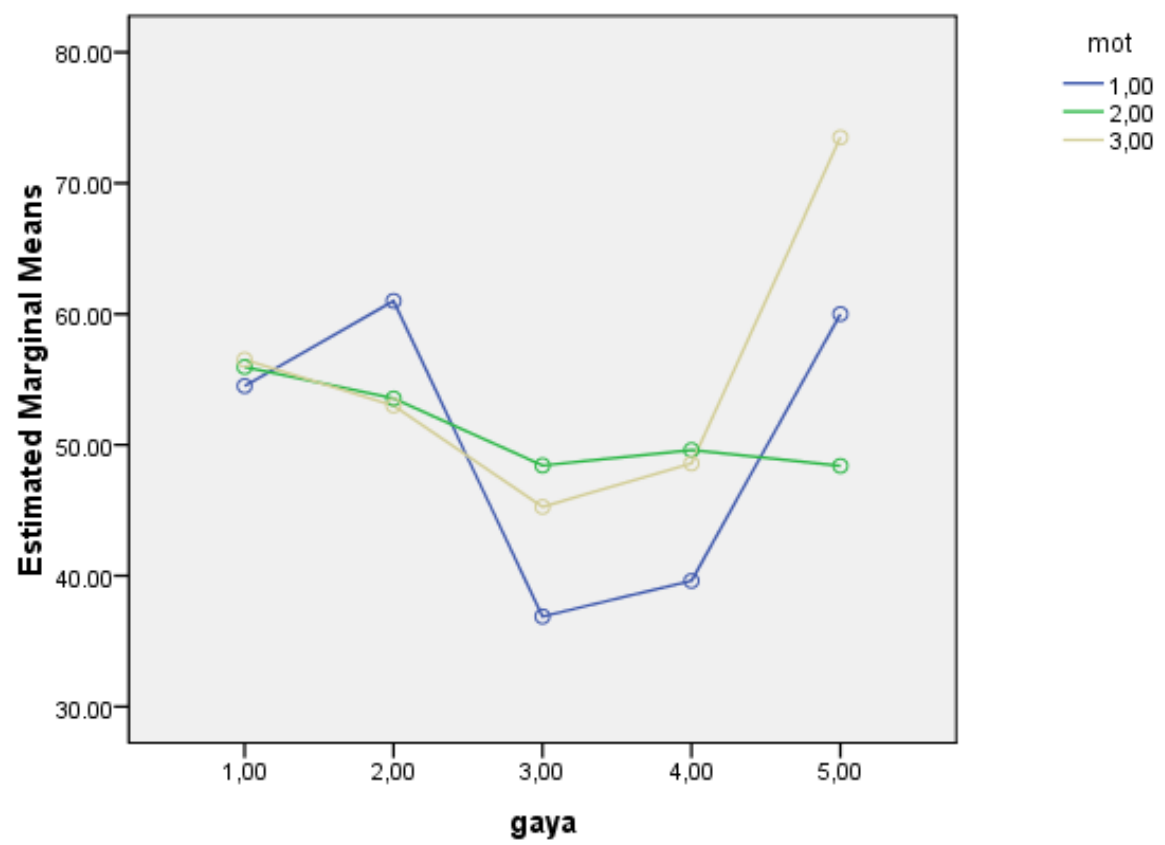

Note: Learning style $1=$ communicative $2=$ concrete $3=$ authority oriented

$$
\begin{array}{cc}
4=\text { analytic } & 5=\text { undecided } \\
\text { Motivation 1= low } \quad 2=\text { mid } & 3=\text { high }
\end{array}
$$

Figure 3 shows that the highest score in English achievement was gained by students who have undecided learning styles with high level of motivation. The second highest score of English was gained by students with communicative learning style who have low motivation of learning. The third highest score of Engish achievement was gained by students who have undecided style with low motivation followed by students with communicative learning style with middle level of motivation. This illustration shows that there is no logical correlation between learing style and motivation. However, there needs to be further clarification from this result. The random patterns of learning styles and motivation on students achievements also contradicts with previous studies on learning style and motivation. Arianti (2013), Utami (2013), and Bakri (2012), all seem to agree that there is a significant correlation between students' learning styles and their achievement on their learning achievement of some content learning. Again, here the differences between the results of the current research and the previous studies are due to differences in formulating paradigm both in terms of selecting construct of learning style and motivation as well as the statistical analysis paradigm.

In terms of construct, many research on learning style use senses of visual, audio, and kinesthetic as the basis for categorizing students' learning style. Meanwhile, the construct offered by Willing (1988) was based on the combination of senses and other affective factor to categorize students who learn a second/foreign language. This has resulted in the category of learning styles into communicative, concrete, authority oriented, and analytical learning style to denote to preference one has in learning a second/foreign language. 


\section{CONCLUSION}

From the analysis, it can be concluded that learning styles have a significant effect on the students' English achievement at junior high schools in Bandar Lampung. Students with different learning styles have different learning achievement. The highest score in English achievement was gained by students with communicative learning styles and undecided learners. A difference is found between the result of the current study and the previous studies in terms of construct paradigm.

Motivation does have a significant effect on students' learning English achievement. Students with high motivation do not have different English achievement from students with middle level of motivation but relatively differ from students with low level motivation.

Multivariate analysis of variant (MANOVA) on the relationship between learning styles and motivation shows that there is no significant interaction between students' learning styles and their motivation toward students' English achievement.

\section{REFERENCES}

Anita, I. (2011). Pengaruh gaya belajar dan motivasi belajar terhadap prestasi belajar pembelajaran melakukan instalasi perangkat jaringan lokal siswa SMK Muhammadiyah 3 Yogyakarta. Unpublished thesis. Yogyakarta: UNY.

Barkhuizen, G.P. (1998). Discovering learners' perceptions of ESL classroom teaching/learning activities in a South African context. TESOL Quarterly, 32, 85-108.

Nunan, D. (1989). Hidden agendas: The role of the learner in programme implementation. In Johnson. R. K. (Ed.), The second language curriculum. Cambridge: Cambridge University Press.

Panduwinata, Y. 2012. Gaya belajar dan strategi belajar menulis pada mata kuliah bahasa inggris di
Politeknik Negeri Lampung. Unpublished Tesis. Lampung: Universitas Lampung

Reid, J. (1987). The learning style preferences of ESL students. TESOL Quarterly, 21, 87-103.

Richards, J. and C. Lockhart. (1994). Reflective teaching in second language classrooms. Cambridge: Cambridge University Press.

Sadewo, S. 2011. Hubungan sikap siswa, motivasi belajar, dan pemanfaatan sumber belajar dengan kemampuan bahasa Inggris siswa Kelas XI MAN 1 Metro. Unpublished thesis. Lampung: Universitas Lampung

Bakri, S. (2013). Hubungan motivasi belajar dan gaya belajar dengan prestasi belajar mata pelajaran ekonomi siswa Kelas XII Program IPS SMA Negeri 2 Bae Kudus. Unpublished thesis. Solo: Universitas Sebelas Maret.

Sari, A. (2013). Pengaruh gaya belajar dan motivasi berprestasi siswa terhadap prestasi belajar praktik instalasi listrik di SMK Negeri 2 Yogyakarta. Jakarta: Universitas Guna Darma.

Setiyadi, A. B. 2006. Metode penelitian untuk pengajaran bahasa asing. Yogyakarta: Graha Ilmu.

Tis'ah, N. (2011). Perbedaan gaya belajar siswa, gaya mengajar guru dan lama belajar siswa di luar sekolah terhadap kemampuan berbahasa Inggris siswa Kelas IX SMP Negeri 16 Bandar Lampung. Unpublished Tesis. Lampung: Universitas Lampung

Utami, E. D. (2013). Hubungan motivasi belajar dan gaya belajar terhadap hasil belajar mata ajar periodonsia pada Fakultas Kedokteran Gigi Univ. Prof. Dr. Moestopo. Digital Library Universitas Sebelas Maret Solo

Willing, K. (1988). Learning styles in adult migration education. Adelaide: National Curriculum Resource Center.

Yufrizal, H. (2000). Negotiation of meaning in EFL dyads in Indonesia: The roles of gender, proficiency, and learning styles. Unpublished doctoral thesis, La Trobe University, Australia.

Yufrizal, H. (2001). Communicative task and learning styles: negotiation of meaning and second language development in Indonesia. TEFLIN

Yufrizal, H. (2009). Gaya Belajar dan gaya mengajar. Bandung: Pustaka Reka Cipta.

Yufrizal, H. (2007). Negotiation of meaning by Indonesian EFL Learners. Bandung: Pustaka Reka Cipta. 